\title{
PENINGKATAN MOTIVASI DAN KEMAMPUAN BERPIKIR KREATIF SISWA PADA MATERI PENCEMARAN LINGKUNGAN MELALUI MEDIA FOTONOVELA
}

\section{Puji Astuti ${ }^{凶}$}

SMA 1 Kudus

\section{Info Artikel}

Sejarah Artikel:

Diterima 28 Sept 2017

Disetujui 28 Okt 2017

Dipublikasikan Des 2017

\section{Keywords:}

motivation and creative

thinking abilities fotonovela

group discussion media

\section{Abstract}

The research problems are how fotonovela group discussions media can increase motivation and creative thinking abilities of students in the matter of environmental pollution. This study was conducted in two cycles each cycle consist of 2 meetings. Research subjects is motivation and creative thinking abilities of students of class X IPA 8 SMA 1 Kudus semester of academic year 2012/2013. The results showed an increase in motivation and creative thinking abilities of students on material environmental pollution by fotonovela group discussions media.

\section{Abstrak}

Rumusan masalah penelitian ini adalah bagaimanakah media diskusi kelompok fotonovela dapat meningkatkan motivasi dan kemampuan berpikir kreatif siswa pada materi pencemaran lingkungan. Penelitian ini dilaksanakan dalam 2 siklus masing-masing siklus 2 kali pertemuan. Subjek penelitian adalah motivasi dan kemampuan berpikir kreatif siswa kelas X IPA 8 SMA 1 Kudus semester genap tahun pelajaran 2012/2013. Hasil penelitian menunjukkan terjadi peningkatan motivasi dan kemampuan berpikir kreatif siswa pada materi pencemaran lingkungan dengan memanfatkan media diskusi kelompok fotonovela.

(C) 2017 Universitas Muria Kudus

\footnotetext{
$\triangle$ Alamat korespondensi:

Program Studi Pendidikan Guru Sekolah Dasar

p-ISSN 2087-9385

Fakultas Keguruan dan Ilmu Pendidikan Universitas Muria Kudus

e-ISSN 2528-696X

Kampus UMK Gondangmanis, Bae Kudus Gd. L. 1t I PO. BOX 53

Kudus

Tlp (0291) 438229 ex.147 Fax. (0291) 437198

E-mail: astutipuji56@gmail.com
} 


\section{PENDAHULUAN}

Materi pencemaran lingkungan merupakan salah satu pokok bahasan Biologi kelas X SMA yang termasuk dalam submateri ekosistem. Materi pencemaran lingkungan tercantum dalam standar kompetensi menganalisis hubungan antara komponen ekosistem, perubahan materi dan energi serta peranan manusia dalam keseimbangan ekosistem.

Kompetensi dasar yang harus dicapai yaitu menjelaskan keterkaitan antara kegiatan manusia dengan masalah perusakan/pencemaran lingkungan dan pelestarian lingkungan serta menganalisis jenis-jenis limbah dan daur ulang limbah. Dengan kata lain, melalui pembelajaran materi pencemaran lingkungan siswa diharapkan dapat berpikir kreatif.

Kenyataan di lapangan menunjukkan bahwa siswa SMA 1 Kudus yang memiliki input tinggi, memiliki motivasi dan kemampuan berpikir kreatif yang kurang maksimal. Sebagai contoh, saat melakukan diskusi kelompok pada materi pencemaran lingkungan, siswa kurang antusias dalam menanggapi ide-ide dari temannya dan merumuskan ide-ide baru atau dengan kata lain motivasi berpikir kreatif siswa masih rendah.

Diskusi kelompok cenderung berjalan lambat dan kurang efektif. Data tahun sebelumnya menunjukkan bahwa rata-rata hasil belajar yang mengukur kemampuan berpikir kreatif pada materi pencemaran lingkungan berupa hasil diskusi kelompok dan hasil ulangan harian $<78$ atau tidak mencapai KKM (80). Hanya $40 \%$ siswa yang mendapatkan nilai $\geq 80$ untuk hasil diskusi kelompok dan nilai ulangan. Siswa masih terpaku untuk sekedar menghafalkan konsep pencemaran lingkungan namun kurang mampu mengemukakan ide kreatif tentang penanggulangan pencemaran lingkungan.

Peneliti berusaha menganalisis penyebab persoalan tersebut melalui diskusi dengan teman sejawat. Salah satu penyebab kurangnya motivasi dan kemampuan berpikir kreatif siswa tersebut disebabkan beberapa faktor. Faktor pertama adalah obyek dan persolan pencemaran lingkungan sangat dekat dengan lingkungan siswa, tetapi lingkungan sekitar siswa hanya dapat menunjukkan sebagian contoh dari materi Pencemaran Lingkungan.

Faktor yang kedua adalah pembelajaran di kelas yang dilakukan guru selama ini kurang memenuhi kebutuhan siswa akan visualisasi proses pencemaran lingkungan. Guru belum pernah membuat media fotonovela dalam bentuk cetak dan guru hanya menggunakan foto-foto tentang pencemaran lingkungan dalam slide presentasi Microsoftpower point.

Penelitian Susandi (2006) menyebutkan bahwa fotonovela membuat pengajaran lebih menarik perhatian dan dapat menumbuhkan motivasi belajar siswa, penyampaian materi pelajaran menjadi lebih jelas maknanya serta mudah dipahami oleh siswa. Penelitian Pratiwi dan Syam (2011) menandaskan bahwa penggunaan fotonovela juga berpengaruh terhadap hasil belajar siswa

Berdasarkan uraian di atas, maka rumusan masalah penelitian ini adalah: 1) bagaimana peningkatan motivasi berpikir kreatif siswa pada materi pencemaran lingkungan dengan memanfaatkan media diskusi kelompok fotonovela? dan 2) bagaimana peningkatan kemampuan berpikir kreatif siswa pada materi pencemaran lingkungan dengan memanfaatkan media diskusi kelompok fotonovela?

Tujuan dari penelitian ini adalah: 1) mendeskripsikan peningkatan motivasi berpikir kreatif siswa pada materi pencemaran lingkungan memanfaatkan mediadiskusi kelompok fotonovela dan 2) mendeskripsikan peningkatan kemampuan berpikir kreatif siswa pada materi pencemaran lingkungandengan memanfaatkan mediadiskusi kelompok fotonovela.

Manfaat penelitian ini bagi peserta didik adalah dapat meningkatkan motivasi dan kemampuan berpikir kreatif pada materi pencemaran lingkungan. Bagi guru diharapkan dapat memberikan contoh media diskusi kelompok yang dapat diterapkan dalam pembelajaran materi pencemaran lingkungan sehingga proses dan hasil belajar siswa dalam berpikir kreatif dapat meningkat. Bagi sekolah, diharapkan dapat mendorong guru dalam meningkatkan kemampuan mengembangkan media pembelajaran.

\section{METODE PENELITIAN}

Penelitian menggunakan metode Penelitian Tindakan Kelas. Pelaksanaan tindakan dalam penelitian melalui proses pembelajaran yang terbagi menjadi 2 siklus.

Siklus pertama, menggunakan fotonovela sebagai media diskusi untuk materi macammacam pencemaran lingkungan. Guru pada awal pertemuan pertama mengulas pokokpokok materi, kemudian siswa berdiskusi dalam kelompok kecil. Pada pertemuan kedua, 1 jam pelajaran perwakilan kelompok siswa mempresentasikan hasil diskusi kelompok di depan kelas dan kelompok lain menanggapi. Pada akhir siklus guru memberi tes uji akhir siklus. 
Siklus kedua, tetap menggunakan fotonovela pada materi penanggulangan pencemaran lingkungan, namun guru telah memberikan tugas kepada siswa untuk mempelajari terlebih dahulu materi di rumah.

Penelitian dilakukan di SMA Negeri 1 Kudus yang terletak di Jalan Pramuka No. 41 Kecamatan Kota, Kabupaten Kudus. Waktu penelitian dimulai bulan Maret sampai Mei 2013 semester genap tahun pelajaran 2012/2013.

Subjek penelitian tindakan kelas ini yaitu motivasi dan hasil belajar siswa kelas X IPA 8 SMA 1 Kudus sebanyak 25 siswa terdiri dari 16 perempuan dan 9 laki-laki dengan pertimbangan peneliti mengajar di kelas tersebut, motivasi dan kemampuan berpikir kreatif siswa terutama dalam melaksanakan diskusi kelompok paling rendah diantara kelas X IPA yang lain.

Teknik pengambilan data dalam penelitian ini adalah tes dan non tes. Teknik tes digunakan untuk mendapat skor tes siswa pada akhir siklus 1 dan 2. Teknik nontes berupa pengamatan performance guru, motivasi siswa dalam diskusi kelompok dan penilaian hasil diskusi kelompok.

Teknik analisis data yang digunakan adalah deskriptif kuantitatif dan kualitatif. Data skor motivasi berpikir kreatif siswa diukur berdasarkan jumlah soal yang dapat diselesaikan siswa. Data kemampuan berpikir kreatif diukur berdasarkan nilai hasil diskusi kelompok dan nilai tes akhir siklus.

Indikator kinerja penelitian ini yakni media diskusi kelompok fotonovela dikatakan dapat meningkatkan motivasi dan kemampuan berpikir kreatif siswa jika: $>80 \%$ siswa mendapatkan nilai motivasi baik dan cukup baik dan $>80 \%$ siswa memperoleh nilai hasil diskusi dan nilai tes $\geq 80$.

\section{HASIL DAN PEMBAHASAN Kondisi Awal}

Diskusi kelompok merupakan salah satu metode yang dapat diterapkan pada pembelajaran biologi, terutama pada materi yang bersifat apresiasi pendapat seperti pencemaran lingkungan. Berdasarkan pengamatan peneliti, kegiatan diskusi kelompok pada siswa kelas X IPA 8 cenderung kurang efektif dan efisien. Hasil diskusi kelompok juga kurang maksimal.

Pada materi ekosistem, hasil diskusi kelompok yang memperoleh nilai $\geq 80$ hanya 12 siswa (44\%) dan nilai ulangan harian $\geq 80$ hanya 16 siswa $(59 \%)$

\section{Hasil Penelitian Siklus I}

Proses pembelajaran pertemuan 1 diawali dengan penjelasan pokok-pokok materi oleh guru yaitu macam pencemaran lingkungan dan dampaknya. Kemudian dilanjutkan dengan pembentukan kelompok dan diskusi kelompok.

Pada pertemuan 2 perwakilan kelompok siswa mempresentasikan hasil diskusi di depan kelas kemudian siswa kelompok lain menanggapi untuk diambil satu kesimpulan. Pada akhir siklus guru memberikan tes uji akhir siklus.

Penelitian ini mengukur motivasi siswa menggunakan lembar observasi jumlah soal pada fotonovela bilingual yang dikerjakan oleh siswa dalam diskusi kelompok. Lembar observasi terdiri dari 6 pertanyaan yang mempunyai 2 kategori jawaban yaitu jawaban ya (skor 1) dan tidak (skor 0). Rentangan skor yang merupakan jenis data interval kemudian dikonversikan menjadi jenis data ordinal berdasarkan jumlah soal yang dapat dikerjakan; dengan kriteria baik(6 soal semua), cukup baik(3-5 soal), kurang baik (2 soal)dan tidak baik(0 soal).

Pelaksanaan penggunaan media fotonovela dalam kegiatan diskusi kelompok menunjukkan bahwa sebanyak 20 siswa dalam kategori cukup baik dan sebanyak 5 siswa dalam kategori kurang baik dan tidak ada satu pun siswa dalam kategori baik. grafik 1.

Hasil penelitian ini dapat dilihat pada

Grafik 1. Motivasi Berpikir Kreatif Siswa pada Siklus I

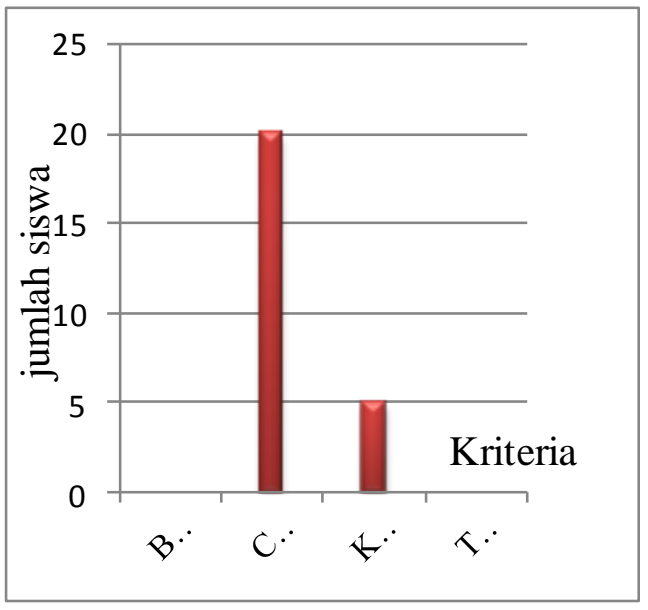

B: baik; C: cukup baik; K: kurang baik; T: Tidak baik

Hasil penelitian tersebut menunjukkan bahwa indikator penelitian belum tercapai, yaitu $>80 \%$ siswa memiliki motivasi berpikir kreatif 
baik dan cukup baik. Hal tersebut terjadi karena siswa belum terbiasa menggunakan media fotonovela dalam diskusi kelompok.

Siswa melakukan pembagian kerja dalam mengerjakan soal dan waktu tidak cukup, sehingga ada sebagian siswa yang tidak ikut mengerjakan seluruh soal. Penyebab lain adalah waktu yang dibutuhkan siswa banyak dalam menyamakan pendapat cukup banyak karena banyak perbedaan pendapat dalam diskusi kelompok.

Hasil observasi kegiatan diskusi kelompok juga menunjukkan bahwa siswa kurang termotivasi untuk menyampaikan ide-ide dalam menjawab masalah pencemaran lingkungan. Presentasi hasil diskusi kelompok juga kurang lancar. Siswa kurang antusias mengemukakan ide-ide kreatif dan menanggapi ide kreatif dari siswa lain. Performance siswa dalam kegiatan diskusi kelompok seperti terlihat pada gambar berikut ini.

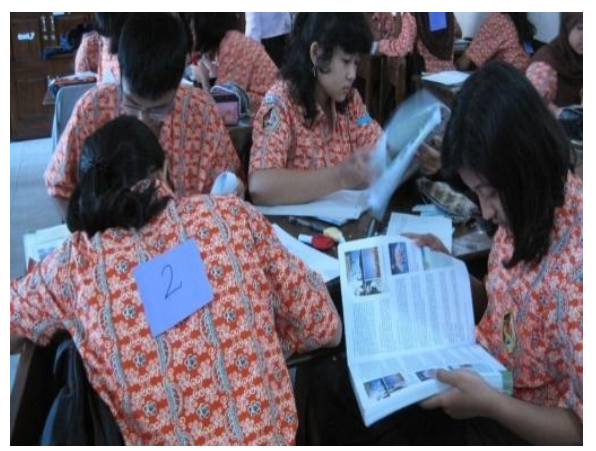

Gambar 1. Kegiatan diskusi kelompok yang kurang lancar pada siklus

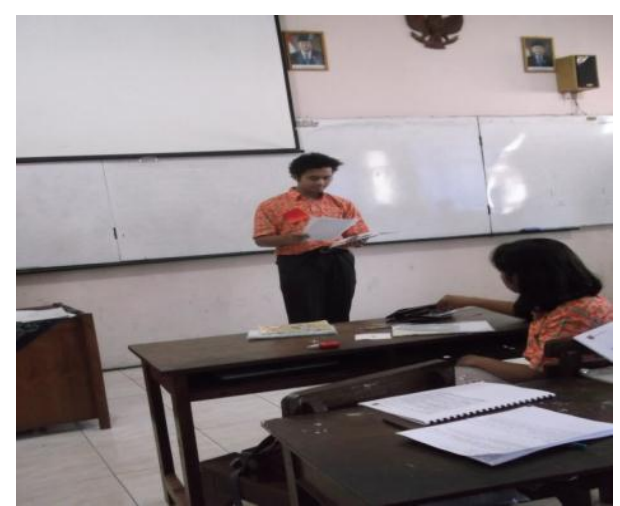

Gambar 2. Siswa kurang aktif menanggapi ide siswa lain saat presentasi siklus I

Data kemampuan berpikir kreatif siswa ditentukan berdasarkan nilai hasil diskusi kelompok yaitu jawaban atas 6 soal pada media fotonovela yang diselesaikan siswa dan hasil tes pada akhir siklus. Nilai hasil diskusi kelompok masih ada yang di bawah 80 sebanyak 13 siswa (52\%).
Siswa yang memperoleh nilai $\geq 80$ hanya 12 siswa (48\%), jadi indikator kinerja belum tercapai. Jawaban siswa terhadap setiap soal kurang lengkap.Data nilai diskusi kelompok pada siklus I seperti terlihat pada grafik 2 .

Grafik 2. Kemampuan Berpikir Kreatif Siswa berdasarkan Nilai Hasil Diskusi Kelompok pada Siklus I

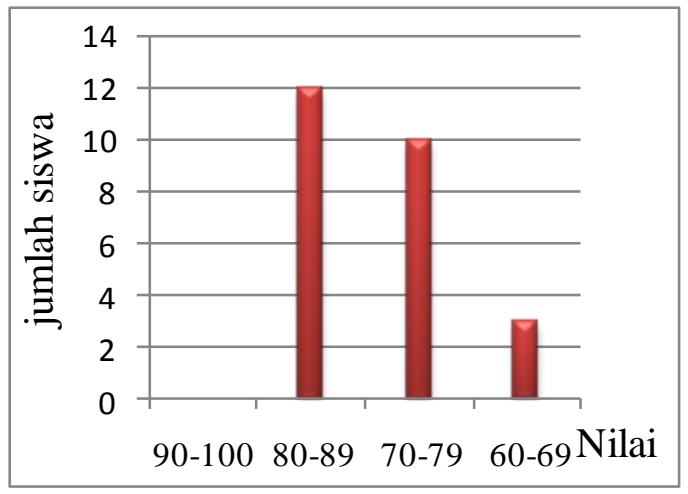

Hasil penelitian menunjukkan bahwa indikator kinerja belum tercapai. Jawaban siswa terhadap setiap soal terutama tentang dampak tindakan terhadap lingkungan kurang lengkap. Hal ini disebabkan dalam menjawab setiap soal tidak didiskusikan oleh semua anggota kelompok tetapi dijawab sendiri. Siswa membagi tugas menjawab soal sehingga jawaban diskusi kelompok kurang komprehensif.

Setelah dilakukan tes akhir siklus I diperoleh hasil bahwa masih ada siswa yang mendapatkan nilai tes di bawah 80 yaitu 9 siswa (36\%), siswa yang menperoleh nilai $\geq 80$ hanya 16 siswa $64 \%$, terdiri dari 3 siswa mendapat nilai 90-100 dan 13 siswa mendapat nilai 80-90. Data hasil tes dapat dilihat pada grafik3.

Grafik 3. Kemampuan Berpikir KreatifSiswa berdasarkan Nilai Tes Akhir Siklus I

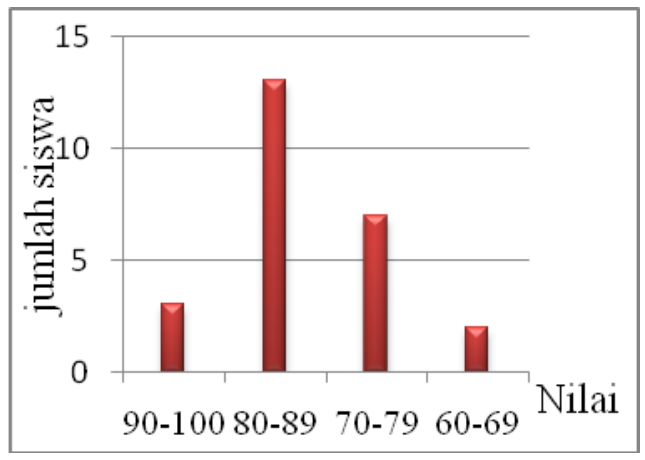

Hasil penelitian menunjukkan bahwa indikator kinerja belum tercapai. Hal itu 
disebabkan siswa belum terbiasa dalam memanfaatkan media diskusi kelompok fotonovela. Diskusi kelompok yang kurang lancar menyebabkan siswa kurang memahami materi pencemaran lingkungan, terutama tentang dampak tindakan manusia terhadap lingkungan.

\section{Hasil Penelitian Siklus II}

Pada siklus II, pembelajaran tetap menggunakan media diskusi kelompok fotonovela, namun setiap siswa terlebih dahulu mendalami materi pencemaran lingkungan di rumah sebelum mengikuti diskusi kelompok. Kegiatan diskusi siswa berjalan lebih efektif.

Semua siswa dalam 1 kelompok terlibat aktif dalam mengungkapkan ide-ide kreatif sesuai masalah yang ditanyakan dalam media fotonovela. Siswa tidak lagi membagi soal melainkan membahas bersama melalui diskusi. Kegiatan presentasi pada pertemuan 2 juga lebih efektif. Siswa lebih antusias menanggapi ide-ide kreatif siswa. Berikut gambar performance siswa saat diskusi kelompok dan presentasi.

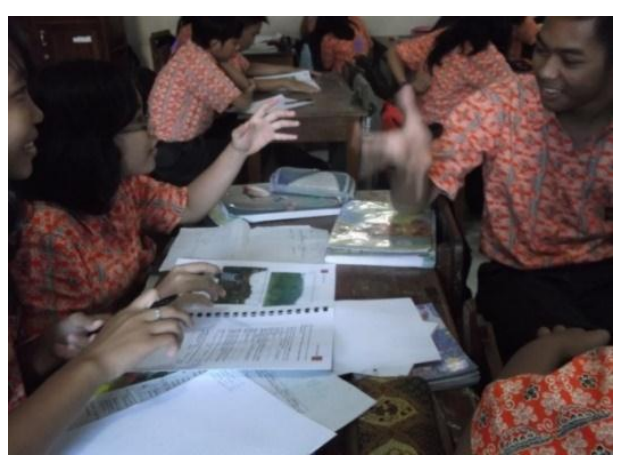

Gambar 3. Aktivitas siswa saat diskusi kelompok siklus II, siswa sangat antusias dan nampak senang dalam bertukar pikiran dan pendapat.

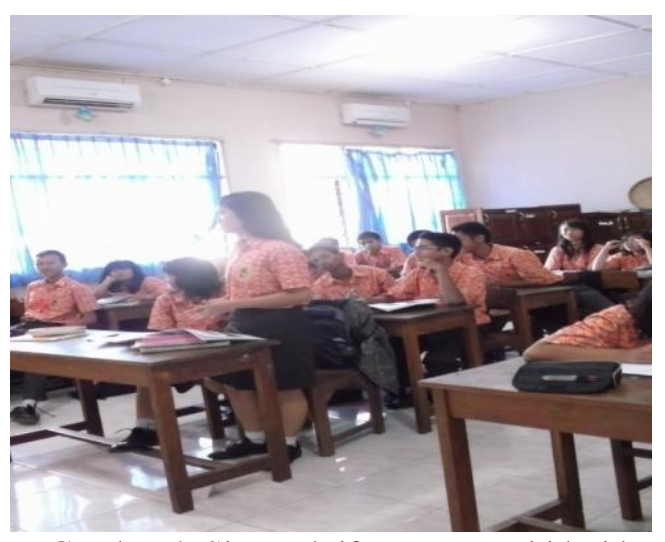

Gambar 4. Siswa aktif menanggapi ide-ide siswa yang presentasi pada siklus II

Hasil observasi terhadap pelaksanaan penggunaan media fotonovela dalam kegiatan diskusi kelompok yaitu rata-rata jumlah soal dalam fotonovela yang dapat diselesaikan oleh siswa, sebanyak 21 siswa dalam kategori baik dan sebanyak 4 siswa dalam kategori cukup baik. Pada kategori baik pun, 21 siswa tersebut dapat menyelesaikan semua soal. Jadi siswa yang memiliki nilai motivasi berpikir kreatif $\geq$ 80 sejumlah 25 siswa (100\%). Hasil selengkapnya seperti terlihat pada grafik 4 .

Grafik 4.Motivasi Berpikir Kreatif

Siswa pada Siklus II

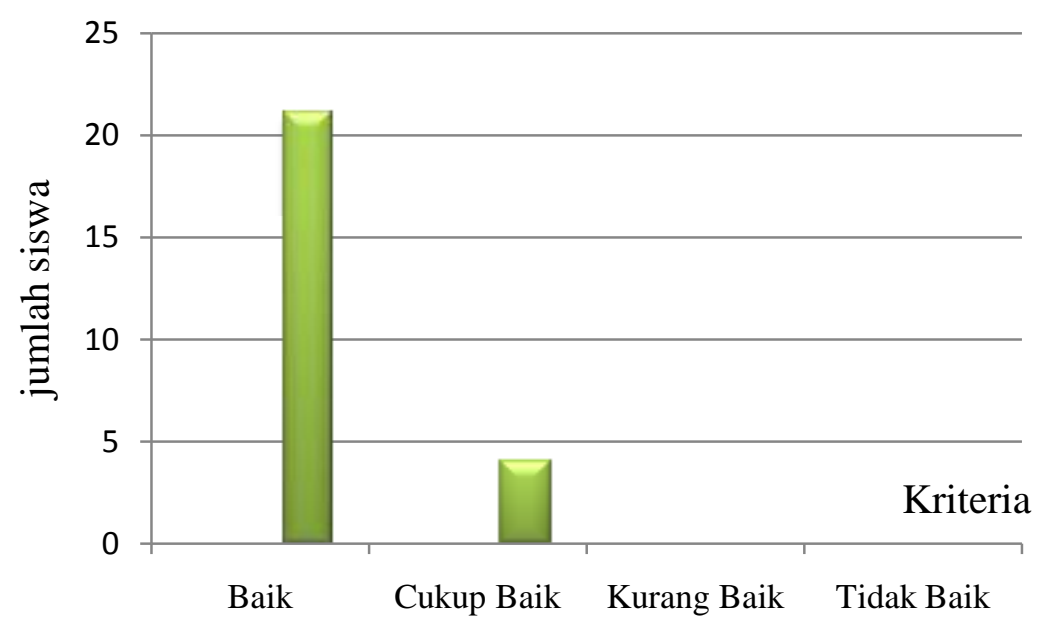


Hasil penelitian menunjukkan ada peningkatan hasil pada siklus II. Hal tersebut terjadi karena semua siswabersama-sama mengajukan pendapat pada setiap soal kemudian siswa menyimpulkan sebagai jawaban kelompok dan ditulis oleh salah satu siswa. Empat siswa yang berkategori cukup baik, hanya menyelesaikan 3 soal. Hal ini disebabkan mereka justru terlalu lama dalam menyatukan pendapatwaktunya habis dan soal lain tidak terjawab.

Data hasil belajar ditentukan berdasarkan nilai jawaban soal pada media fotonovela yang diselesaikan siswa dalam diskusi kelompok dan hasil tes akhir siklus. Nilai hasil diskusi kelompok yaitu siswa yang mendapatkan nilai hasil diskusi kelompok di bawah 80 hanya 4 siswa (16\%). Siswa yang menperoleh nilai $\geq 80$ meningkat menjadi 21 siswa $(84 \%)$. Hasil penelitian seperti terlihat pada grafik 5 berikut.

Grafik 5. Kemampuan Berpikir Kreatif Siswa berdasarkan Nilai Hasil Diskusi Kelompok Siklus II

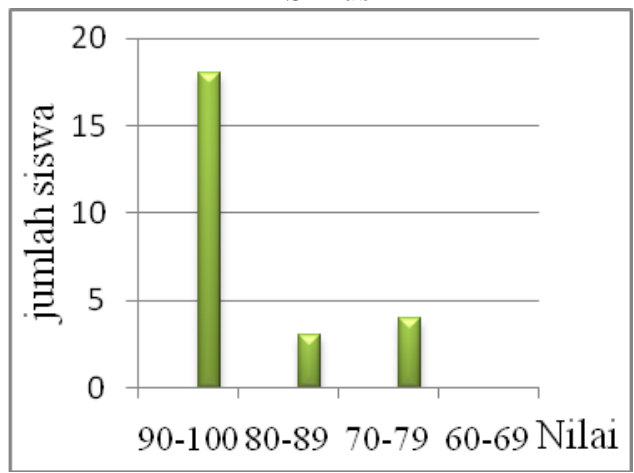

Hasil penelitian tersebut menunjukkan bahwa indikator kinerja sudah tercapai. Ada peningkatan hasil pada siklus II. Jawaban siswa terhadap setiap soal terutama tentang tindakan atau solusi terhadap masalah pencemaran lingkungan lebih lengkap. Ide kreatif siswa juga terlihat dalam bentuk poster tentang cara menanggulangi masalah pencemaran lingkungan.

Setelah dilakukan tes akhir siklus II diperoleh hasil sebagai berikut. Siswa yang mendapatkan nilai tes di bawah 80 yaitu hanya 1 siswa (4\%), siswa yang menperoleh nilai $\geq$ 80 menjadi $96 \%$ dimana 10 siswa $(30 \%)$ mendapatkan nilai 93 dan 5 siswa yang mendapatkan nilai 100. Hasil penelitian seperti terlihat pada grafik 6 .
Grafik 6. Kemampuan Berpikir Kreatif Siswa berdasarkan Nilai Tes Akhir Siklus II

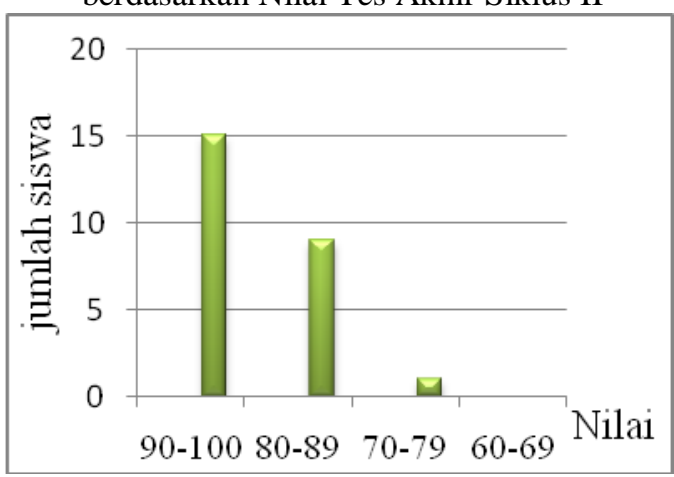

Hasil penelitian tersebut menunjukkan bahwa indikator kinerja sudah tercapai yaitu> $80 \%$ siswa mendapatkan nilai tes $\geq 80$. Ada peningkatan kemampuan berpikir kreatif pada siklus 2.

\section{Pembahasan}

\section{Motivasi Berpikir Kreatif Siswa}

Peningkatan motivasi berpikir kreatif siswa antar siklus I dengan siklus II adalah sebagai berikut. Pada siklus I, jumlah siswa yang memiliki motivasi baik sejumlah 0 siswa, cukup baik sejumlah 4 siswa dan kurang baik sejumlah 4 siswa. Pada siklus II, siswa yang memiliki motivasi baik sejumlah 21 siswa, cukup baik 5 siswa dan kurang baik 0 siswa.

Indikator penelitian yaitu > $80 \%$ siswa memiliki motivasi berpikir kreatif baik dan cukup baik. Hasil penelitian menunjukkan bahwa pada siklus I terdapat $80 \%$ siswa yang mencapai indikator penelitian sedangkan pada siklus II meningkat menjadi $100 \%$ seperti yang terlihat pada grafik 7 .

Grafik 7. Peningkatan motivasi berpikir kreatif siswa antar siklus I dan II.

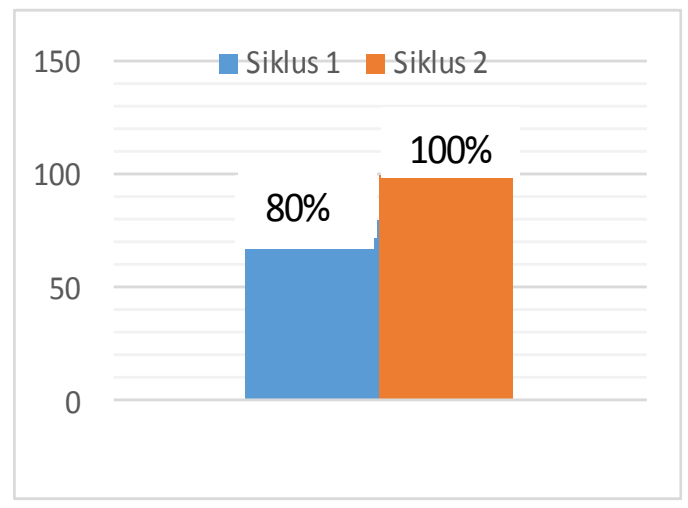

Hasil di atas menunjukkan bahwa terjadi peningkatan motivasi berpikir kreatif pada siswa antara siklus I dengan siklus II. Hal itu disebabkan, siswa telah terbiasa menggunakan 
media diskusi kelompok fotonovela. Siswa dapat menjawab persoalan-persoalan pada media fotonovela melalui diskusi kelompok. Siswa lebih cepat antusia dalam menyampaikan ide-ide dan dapat segera dirumuskan kesepakatan pendapat terhadap persoalan yang didiskusikan.

Data penelitian menunjukkan bahwa ada peningkatan motivasi berpikir kreatif siswa dengan menggunakan media diskusi kelompok fotonovela. Hal ini sesuai dengan landasan teori yaitu hasil penelitian Susandi (2006) dan Syam (2011) bahwa dengan media foto membuat pengajaran lebih menarik perhatian, dapat menumbuhkan motivasi belajar siswa. Hasil penelitian Pratiwi (2011) juga sesuai hasil penelitian ini yaitu media fotonovela memiliki pengaruh terhadap aktivitas siswa pada mata pelajaran biologi.

\section{Kemampuan Berpikir Kreatif Siswa}

Kemampuan berpikir kreatif siswa diukur pertama dari nilai hasil diskusi kelompok dan niali tes. Hasil penelitian menunjukkan bahwa ada peningkatan hasil jawaban diskusi kelompok siswa sebagaimana yang terlihat pada grafik 8 . Pada siklus I siswa yang mendapatkan nilai $\geq 80$ sejumlah 12 siswa (48 \%) dan meningkat pada siklus II menjadi 21 siswa (84 $\%)$.

Grafik 8. Peningkatan Kemampuan Berpikir Kreatif Siswa berdasarkan nilai hasil diskusi kelompok antara Siklus I dan Siklus II

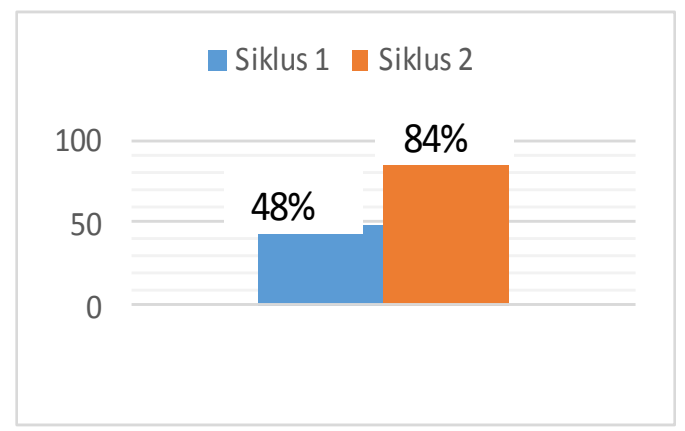

Peningkatan hasil diskusi juga ditentukan berdasarkan uraian jawaban siswa dalam menjawab persoalan pencemaran lingkungan. Jawaban siswa lebih divergen dan komprehensif. Siswa mampu menganalisis persoalan sekaligus menghasilkan ide-ide kreatif untuk menanggulangi masalah pencemaran lingkungan. Seperti membuat bio filter, penggunaan bahan bakar rendah karbondioksida dan karbonmonoksida, pembuatan alat penyaringan knalpot kendaraan bermotor serta usaha-usaha sosialisasi kepada masyarakat tentang upaya pengurangan limbah dan pencemaran lingkungan.

Hasil penelitian tersebut sesuai dengan penelitian Susandi (2006) dan Syam (2009) bahwa media fotonovela berpengaruh terhadap hasil belajar. Hasil penelitian Pratiwi (2011) juga selaras dengan hasil penelitian ini bahwa media fotonovela memiliki pengaruh terhadap hasil belajar pada mata pelajaran biologi.

Indikator kedua untuk kemampuan berpikir kreatif siswa adalah nilai hasil ulangan harian. Hasil penelitian menunjukkan bahwa ada peningkatan nilai tes antara siklus I dengan siklus II seperti pada grafik 9. Jumlah siswa yang mendapatkan nilai $\geq 80$ adalah 16 siswa (64\%) dan pada siklus 2 menjadi 24 siswa (96\%). Data penelitian seperti terlihat pada grafik 9 berikut ini.

Grafik 9. Peningkatan Kemampuan Berpikir Kreatif Siswa berdasarkan Nilai Tes Siklus I dan II

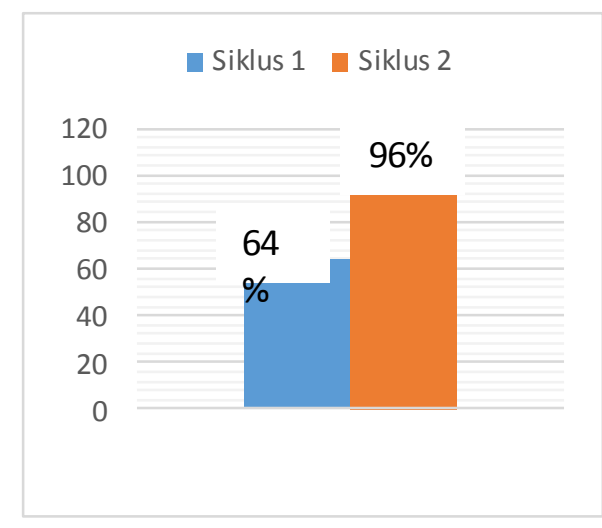

Secara keseluruhan, hasil penelitian ini menunjukkan bahwa motivasi berpikir kreatif siswa pada materi pencemaran lingkungan dapat meningkat dengan menggunakan media diskusi kelompok fotonovela. Pertanyaan-pertanyaan yang bersifat terbuka jawabannya dan disertai gambar foto pencemaran lingkungan yang menarik dapatmeningkatkan motivasi siswa.

Siswa lebih antusias dalam mengikuti kegiatan diskusi kelompok. Ide-ide siswa dapat lebih terungkap dan menghasilkan kesimpulan jawaban yang baik. Akibatnya nilai hasil diskusi kelompok meningkat, demikian juga nilai tes.

\section{PENUTUP \\ Simpulan}

Media diskusi kelompok dapat meningkatkan motivasi dan kemampuan berpikir kreatif siswa pada materi pencemaran lingkungan. Dengan contoh pencemaran yang ada di sekitar lingkungan siswa dalam foto, 
motivasi siswa untuk menjawab soal berupa analisis kasus menjadi meningkat.

Siswa menjadi lebih antusias untuk terlibat dalam diskusi kelompok karena media yang menarik. Hal itu dapat meningkatkan kemampuan berpikir kreatif siswa berupa nilai hasil diskusi kelompok dan nilai ulangan.

Saran

Berdasarkan hasil penelitian tindakan kelas ini dapat disampaikan saran sebagai berikut:

1. Bagi guru biologi lain, proses dari penelitian ini dapat diterapkan pada materi biologi lain dengan sedikit memodifikasi untuk meningkatkan motivasi dan hasil belajar.

2. Perlu dilakukan tindak lanjut dari hasil penelitian ini dalam kegiatan belajar mengajar di sekolah.

\section{DAFTAR PUSTAKA}

Cahya RE. 2010. Pemanfaatan Media Foto Pada Pembelajaran Sistem Reproduksi Manusia Siswa Kelas XI IPA 1 SMA N 1 Kembang Kabupaten Jepara Tahun Ajaran 2009/2010 (Skripsi). Solo: Universitas Muhammadiyah Surakarta. On line athttp://garuda.dikti.go.id/ [diakses tanggal 3 Maret 2011].

Matiella AC. 2007. What is a Fotonovela?. Mexico: Arthritis Foundation. On line athttp://www.fotonovelacompany.com/ [diakses tanggal 2 Januari 2011].

Nurlinda L. 2004. Model pembelajaran menulis karangan narasi dengan menggunakan media foto sebagai upaya meningkatkan kemampuan .siswa kelas 3 SMPN 12 Bandung tahun ajaran 2004/2005 (Skripsi). Bandung: Universitas Pendidikan Indonesia. On line athttp://digilib.upi.edu/ [diakses tanggal 3 Maret 2011].

Pratiwi DN. 2011. Efektivitas penerapan kunci determinasi dan fotonovela dengan investigasi kelompok pada pembelajaran klasifikasi makhluk hidup di SMP 1 Karang Pucung Kabupaten Cilacap (Skripsi). Semarang: Universitas Negeri Semarang.
Ridayani. 2007. Pengaruh media foto berwarna dalam pembelajaran sains untuk meningkatkan hasil belajar pada anak low vision (Studi eksperimen single subject research terhadap anak low vision kelas D5 di SLBN-A Citeureup Cimahi) (Skripsi). Bandung: Universitas Pendidikan Indonesia. On line athttp://digilib.upi.edu/ [diakses tanggal 3 Maret 2011].

Sanjaya W. 2007. Strategi Pembelajaran Berorientasi Standar Proses Pendidikan. Jakarta: Kencana.

Susandi A. 2006. Penggunaan media fotonovela model flash card untuk meningkatkan kemampuan berbahasa indonesia siswa sekolah dasar (Penelitian Tindakan Kelas di Kelas IV SDN Neglasari Ciranjang Cianjur) (Skripsi). Bandung: Universitas Pendidikan Indonesia. On line athttp://digilib.upi.edu/ [diakses tanggal 25 Maret 2011].

Sutjiono TWA. 2010. Pendayagunaan media pembelajaran. Jurnal Pendidikan Penabur No.04/Th IV/Juli 2005. On line at http://www.bpkpenabur.or.id/ [diakses tanggal 2 Januari 2011].

Syam K. 2011. Menggunakan Fotonovela dan Guiding Question untuk meningkatkan kemampuan siswa kelas VIII dalam menulis teks naratif di SMPN 21 Malang (Skripsi). Malang: Universitas Malang.

Tim Pengembangan Buku. 2007. Mengembangkan Media Komunikasi Berbasis Masyarakat. Jakarta: Partnership for e-Prosperity For The Poor (Pe-PP), Bappenas-UNDP. On line athttp://www.kangazul.org/ [diakses tanggal 5 Februari 2011]. 